\title{
Meningkatkan kemampuan berpikir kreatif melalui penerapan model pembelajaran JUCAMA
}

\author{
Nur Rahmah Wardani, Juariah, Ida Nuraida dan T. Tutut Widiastuti A \\ Pendidikan Matematika, Fakultas Tarbiyah dan Keguruan \\ UIN Sunan Gunung Djati Bandung, Jl. A.H. Nasution No. 105, Bandung \\ *rahmanrw9@gmail.com
}

Received: 12 Oktober 2020; Accepted: 11 Juni 2021; Published: 30 Juni 2021

\begin{abstract}
Abstrak
Di abad ini, pendidikan menjadi lebih penting untuk memastikan siswa mendapatkan kreatifiatas maka dalam pengembangan kreatifitas secara umum maupun berpikir kreatif matematis pun menjadi penting. Namun, fakta dilapangan ditemukan kemampuan berpikir siswa masih kurang dan perlu ditingkatkan. Tujuan penelitian ini untuk mengetahui perbedaan peningkatan kemampuan berpikir kreatif matematis siswa setelah memperoleh pembelajaran JUCAMA (Pengajuan dan Pemecahan Masalah) serta perbedaan pencapaian kemampuan berpikir kreatif matematis berdasarkan kategori PAM. Metode penelitian yang digunakan adalah metode kuasi eksperimen dengan desain Non Equivalent Control Group Desain yang sampel nya diambil secara purposive sampling di salah satu sekolah Menengah Pertama di daerah Bandung. Dengan menggunakan instrumen tes PAM dan Tes Kemampuan Berpikir Kreatif ini menghasilkan beberapa temuan, yaitu: terdapat perbedaan peningkatan kemampuan berpikir kreatif matematis siswa yang menggunakan model pembelajaran JUCAMA dengan model konvensional (Pembelajaran langsung), dengan rata-rata N-Gain kelas JUCAMA o,16 > kelas konvensional o,10. Model pembelajaran JUCAMA ini berbasis pemecahan dan pengajuan masalah karena keduanya mendorong berkembangnya kreatifitas sehingga mampu meningkatkan kemampuan berpikir kreatif matematis. Dapat disimpulkan setelah siswa memperoleh pembelajaran dengan model pembelajaran JUCAMA lebih baik dari pembelajaran konvensional.
\end{abstract}

Kata kunci: Berpikir Kreatif, JUCAMA, Pemecahan Masalah, Pengajuan Masalah

\begin{abstract}
In this century, education is becoming more important to ensure students get creativity, so in general the development of creativity and mathematical creative thinking is also important. However, the facts in the field found that students' thinking skills were still lacking and needed to be improved. The purpose of this study was to determine the differences in the improvement of students' mathematical creative thinking skills after obtaining JUCAMA (Problem Submission and Solving) learning and the differences in the achievement of mathematical creative thinking abilities based on the PAM category. The research method used is a quasiexperimental method with a Non Equivalent Control Group Design whose samples were taken by purposive sampling in one of the junior high schools in the Bandung area. Using the PAM test instrument and the Creative Thinking Ability Test resulted in several findings, namely: there are differences in the improvement of students' mathematical creative thinking skills using the JUCAMA learning model with the conventional model (Direct learning), with an average JUCAMA class N-Gain o.16 > conventional class o.1O. This JUCAMA learning model is based on problem solving and proposing because both encourage the development of creativity so as to improve mathematical creative thinking skills. It can be concluded that after students get learning with the JUCAMA learning model, it is better than conventional learning.
\end{abstract}

Keywords: Creative thinking skill, JUCAMA, Problem Based, Problem Posing 
Nur Rahmah Wardani, Juariah,

Ida Nuraida dan T. Tutut Widiastuti A

\section{PENDAHULUAN}

Dalam memenuhi kebutuhan akan keterampilan abad 21 ini sangat bergantung pada konteks dengan beragam aspek. Wrahatnolo dan Munoto melakukan penelitian yang menemukan bahwa penerapan keterampilan abad 21 memiliki manfaat yang lebih terukur di beberapa bagian kehidupan, seperti berpikir kritis dan pemecahan masalah, inisiatif, kreativitas, dan kewirausahaan, komunikasi, kerja tim, metakognisi (perubahan pola pikir), sastra digital. Selanjutnya, disebutkan bahwa pikiran kreatif individu semuanya bergantung pada lingkungan kerja, pengetahuan, dan keterampilan memecahkan masalah. Di abad ini, pendidikan menjadi lebih penting untuk memastikan siswa mendapatkan keterampilan, kemampuan inovasi, kreativitas, kerja tim, dan belajar bagaimana menggunakan keterampilan hidup dalam hidup mereka. Masalah muncul dari pentingnya dan keunggulan keterampilan untuk masa depan mereka.

Pendidik sejatinya berusaha mengembangkan kemampuan berpikir kreatif siswa tetapi kenyataan yang terjadi ialah siswa ditekan pemahamannya namun belum melibatkan kemampuan berpikir kreatifnya. juga kurikulum saat ini menjadikan pemahaman konsep yang diprioritaskan oleh pendidik. Masalah yang muncul adalah tidak semua pembelajaran matematika memberikan peluang siswa untuk meningkatkan kemampuan berpikir kreatif mereka. Sering kali, hanya berorientasi pada terpenuhinya jumlah materi yang diberikan. Hasil penelitian Shalahuddin, Susanto, \& Parta, (2019) Alhasil pengembangan kemampuan berpikir kreatif siswa tidak maksimal. Masalah lain adalah disebutkan bahwa guru sulit untuk mengajarkan siswa berpikir kreatif (Bona, 2019).

Kemampuan berpikir kreatif yang didefinisikan oleh Semiawan (Hendriana \& Soemarmo, 2017) adalah penerapan dalam pemecahan masalah dengan menyusun ide-ide baru, dan kemampuan mengidentifikasi serta mengasosiasi antara lebih dari satu ide. Kemampuan berpikir kreatif merupakan hal esensial yang perlu dikuasai sesuai dengan matematika yang bertujuan untuk melatih pola berpikir yang terbuka dan objektif serta pola pikir yang kritis, logis, sistematis, cermat dan kreatif demi menghadapi masalah dalam kehidupan perubahan masa depan.

Dalam mengukur kemampuannya terdapat indikator sebagaimana menurut Silver (Agustina \& Noor, 2016) berpikir kreatif dapat diartikan sebagai kemampuan untuk memandang berbagai ragam kemungkinan penyelesaian masalah. Silver dalam (Mulyaningsih \& Ratu, 2017) menyebutkan ada tiga komponen didalamnya yaitu kelancaran (menyelesaikan masalah dengan beragam solusi maupun jawaban), fleksibilitas (siswa dalam memecahkan masalah dengan satu metode atau cara dan masih bisa memecahkan masalah dengan menggunakan cara lain lagi), dan kebaruan (sebagaimana siswa mampu memeriksa jawaban yang sudah selesai dengan beragam cara atau metode, kemudian membuat lainnya lagi yang berbeda).

Dalam menghadapi zaman yang terus berkembang dan kehidupan yang modern maka kita perlu memperbaiki dan meningkatkan kreatifitas siswa seperti dalam menyelesaikan soal-soal berpikir kreatif. Salah satu solusi yang bisa mengatasi permasalahan ini yaitu dengan pemilihan model, pendekatan, metode dan strategi pembelajaran yang tepat. Penggunaan konsep masalah untuk upaya mendorong berpikir kreatif matematis dilakukan karena seseorang akan berpikir yang kemudian terciptalah hasil kreasi manusia sebagai pemecahan masalah. Dengan dilakukannya pemecahan masalah hingga mengajukan masalah akan terus membuat manusia berpikir dan menciptakan kreasi.

Masalah matematika hadir dalam soal non rutin atau soal kata yang tidak bisa diselesaikan hanya dengan menggunakan rumus tertentu saja tetapi untuk menyelesaikannya diperlukan 
Meningkatkan kemampuan berpikir kreatif melalui penerapan model pembelajaran JUCAMA

prosedur yang benar dan pemikiran yang lebih dalam. Menurut Saragih dan Habeahan (2019) Pemecahan masalah bukan hanya tujuan pembelajaran matematika tetapi juga sarana utama pembelajaran matematika serta mengatakan bahwa pemecahan masalah merupakan bagian dari proses standar matematika yang sangat penting karena dalam proses pembelajaran dan penyelesaian siswa diperbolehkan menggunakan kemampuan dan pengalaman yang harus mereka terapkan dalam menyelesaikan masalah non rutin.

Selain itu, Ellerton dalam Xie dan Masingila (2017) menyebutkan bahwa dalam beberapa dekade terakhir, kemajuan signifikan telah dibuat untuk menempatkan pemecahan masalah di jantung matematika sekolah. Sedangkan untuk problem posing, meskipun banyak studi telah dilakukan untuk mengeksplorasi sifatnya, seperti strategi dan proses problem posing, hal ini jarang dilihat sebagai bagian dari kurikulum sekolah. Selain itu, meskipun guru dan siswa mampu mengajukan masalah matematika, mereka masih mengalami kesulitan dalam mengajukan masalah terbuka dan masalah yang berkaitan dengan konsep matematika tertentu atau membedakan berbagai jenis masalah yang diajukan karenanya peneliti merasa baik guru dan siswa perlu mempraktikkan problem posing lebih banyak.

Dengan kesamaan dari pemecahan dan pengajuan masalah dilansir gabungan dua pekerjaan tersebut maupun menghasilkan banyak variasinya sehingga memungkinkan siswa berkembang kemampuan berpikir kreatifnya. Menurut Siswono (2018) peningkatan kemampuan kefasihan, fleksibilitas, maupun kebaruan dengan Model JUCAMA (Pengajuan dan Pemecahan Masalah) diindikasi dalam memecahkan maupun mengajukan masalah matematika yang dilakukan oleh siswa. Penggunaan model pembelajaran yang sesuai merupakan upaya untuk meningkatkan kemampuan berpikir kreatif matematis. Baghetto (Siswono, 2018) menuliskan bahwa telah dilakukan identifikasi terhadap kendala-kendala dalam pengembangan kreatifitas di kelas dengan temuan bahwa praktik pengajaran yang terjadi berupa pengajaran konvergen, pengaruh sikap dan keyakinan guru terhadap kreatifitas, dorongan yang ada pada lingkungan, dan kreatifitas yang ada pada keyakinan siswa. Model pembelajaran berorientasi khusus pada upaya pengembangan berpikir kreatif matematis tidak banyak ditemukan. Karenanya model pembelajaran JUCAMA (Pengajuan dan Pemecahan Masalah) hadir menjadi harapan dapat meningkatkan kemampuan berpikir kreatif matematis siswa.

Jika guru percaya bahwa ahli matematika adalah pemecah masalah, dan sebagai guru menginginkan peserta didiknya menjadi ahli matematika, maka kita perlu mendorong anakanak kita untuk memecahkan masalah dengan cara mereka sendiri (Fox dkk, 2010). Selanjutnya guru perlu mengembangkan lingkungan, di mana peserta didik belajar berpikir kreatif dan kritis dalam suatu kerangka sosial. Tidak hanya itu, perlu juga untuk membatasi pengalaman pemecahan masalah anak-anak pada kumpulan masalah kata untuk dinilai "apakah mereka dapat menerapkan keterampilan yang dipelajari dalam pelajaran sebelumnya?”. Mengembangkan kreativitas anak dalam pemecahan masalah dan mendorong mereka untuk berpikir matematis membutuhkan lingkungan belajar yang sesuai untuk dibangun dan dibina oleh guru. Lingkungan ini perlu mencakup tugas dan aktivitas yang kaya dan bebas bagi peserta didik untuk mengeksplorasi aktivitas tersebut. Sehingga mereka menjadi pemecah masalah yang percaya diri, kompeten, dan kreatif. Ini juga harus menjadi lingkungan yang aman di mana anak-anak tidak takut untuk 'mencoba' dan membuat kesalahan.

Menurut Brown dan Walter (2005) disebutkan bahwa Pengajuan Masalah dan Pemecahan Masalah berkaitan erat. Mengajukan masalah dapat memberdayakan peserta didik saat mereka sendiri memutuskan pertanyaan yang akan dipecahkan, sehingga menghilangkan 
asumsi bahwa hanya ada satu cara untuk memecahkan masalah dan hanya satu jawaban yang benar (Fox dkk, 2010)

Brown dan Walter juga menyebutkan memecahkan masalah sering kali mengarah pada pengajuan masalah. Mereka juga membuat poin bahwa 'tindakan pemecahan masalah membutuhkan beberapa reformulasi dari masalah asli yang pada dasarnya merupakan kegiatan yang menghasilkan masalah'. Dengan demikian, pelajar yang merasa percaya diri dalam menghasilkan masalah mereka sendiri cenderung merasa percaya diri dan percaya diri dalam mengajukan pertanyaan tentang diri mereka sendiri dan orang lain tentang masalah orang lain. Mereka menyarankan fase pertama pengajuan masalah adalah 'Menerima'.

Pada penelitian ini akan dilihat adakah perbedaan peningkatan kemampuan berpikir kreatif matematis antara siswa yang menggunakan model pembelajaran JUCAMA (Pengajuan dan Pemecahan Masalah) dan siswa yang menggunakan model pembelajaran konvensional serta adakah perbedaan pencapaian kemampuan berpikir kreatif matematis antara siswa yang menggunakan model pembelajaran JUCAMA (Pengajuan dan Pemecahan Masalah) dengan siswa yang menggunakan model pembelajaran konvensional berdasarkan tingkat Pengetahuan Awal Matematika (PAM) yang kategorinya tinggi, sedang dan rendah?

Model pembelajaran JUCAMA (Pengajuan dan Pemecahan Masalah) bertujuan meningkatkan kemampuan berpikir kreatif melalui pembelajaran yang aktif secara mental berfokus pada pemecahan dan pengajuan masalah. Pembelajaran berbasis pemecahan masalah mendorong siswa untuk berpikir kreatif. Dalam merespon atau mengatasi halangan serta kendala, pemecahan masalah muncul sebagai proses berpikirnya. Menurut Pehkonen (Pehkonen, 1997) keterampilan kognitif umum berkembang sejalan dengan proses pemecahan masalah dilalui, hal ini menumbuhkan kreatifitas hingga motivasi untuk belajar matematika. kemampuan berpikir kreatif matematis adalah produk kreatifitas dari pemecahan masalah yang dilakuka. Pengajuan masalah (problem posing) merupakan proses yang berdasar pada pengalaman matematika kemudian siswa mengkontruksi penafsiran sendiri terhadap situasi konkret dan merumuskannya menjadi masalah matematika yang memiliki arti. Proses mengajukan masalah muncul ketika siswa dihadapkan dengan sebuah konsep yang biasa bagi mereka. Pertanyaan mengapa, bagaimana jika, atau bilamana bisa muncul sebagai produk hasil berpikir.

Dengan demikian, penggabungan kedua aktifitas pemecahan masalah maupun pengajuan masalah akan memberi hasil yang lebih efektif karena kedua proses terebut memiliki kesamaan yang saling berhubungan dalam upaya mengembangkan kreatifitas. Menilai kemampuan berpikir kreatif siswa menggunakan pengajuan masalah dan pemecahan masalah Silver (Silver, 1997) memberikan indikator yang hubungannya tersebut termuat pada Tabel 1.

Tabel 1.Hubungan Pemecahan dan Pengajuan Masalah dengan Indikator Berpikir Kreatif.

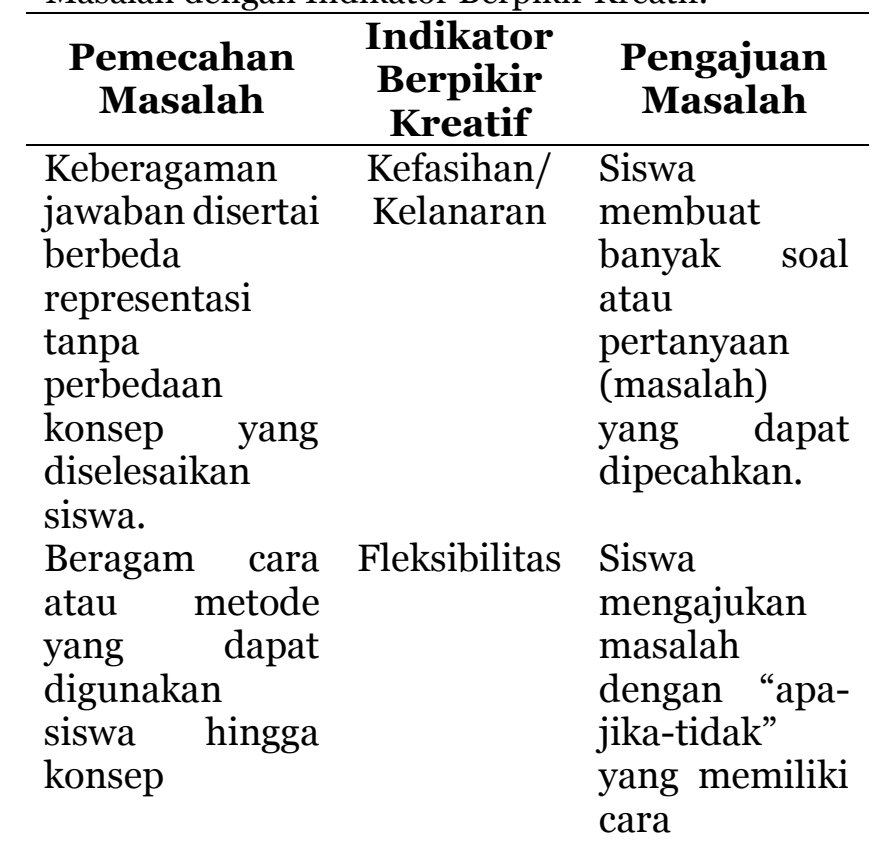


Meningkatkan kemampuan berpikir kreatif melalui penerapan model pembelajaran JUCAMA

\begin{tabular}{|c|c|c|}
\hline $\begin{array}{l}\text { Pemecahan } \\
\text { Masalah }\end{array}$ & $\begin{array}{c}\text { Indikator } \\
\text { Berpikir } \\
\text { Kreatif } \\
\end{array}$ & $\begin{array}{c}\text { Pengajuan } \\
\text { Masalah }\end{array}$ \\
\hline $\begin{array}{l}\text { penggunaan } \\
\text { yang berbeda }\end{array}$ & & $\begin{array}{l}\text { penyelesaian } \\
\text { berbeda-beda } \\
\text { (beda konsep). }\end{array}$ \\
\hline $\begin{array}{l}\text { Mencetus } \\
\text { metode baru } \\
\text { yang berbeda } \\
\text { dari umumnya. }\end{array}$ & Kebaruan & $\begin{array}{l}\text { Siswa } \\
\text { menbuat } \\
\text { masalah lain } \\
\text { yang berbeda } \\
\text { namun tetap } \\
\text { berkaitan. }\end{array}$ \\
\hline
\end{tabular}

\section{METODE}

Penelitian dilaksanakan di salah satu sekolah menengah pertama negeri di kota Bandung dengan mneggunakan metode penelitian yaitu kuasi eksperimen (eksperimen semu). Dengan sebanyak dua kelompok yang diteliti yaitu kelompok eksperimen sebagai kelompok yang menggunakan model pembelajaran JUCAMA (pengajuan dan pemecahan masalah) disebut Kelas JUCAMA dan kelompok kontrol yang akan menjadi pembanding yaitu kelompok yang menggunakan pembelajaran konvensional yang selanjutnya disebut kelas Konvensional. Variabel penelitian terdiri dari variabel bebas (pembelajaran matematika dengan menggunakan model pembelajaran JUCAMA (pengajuan dan pemecahan masalah), variabel terikat (kemampuan berpikir kreatif matematis siswa), dan variabel pengontrol (Pengetahuan Awal Matematika) yang dibagi menjadi kategori tinggi, sedang, dan rendah). Siswa dikelompokan berdasarkan tes Pengetahuan Awal Matematika (PAM) sebelum diberi perlakuan yang selanjutnya diberikan tes kemampuan berpikir kreatifmatematis. Desain eksperimen yang digunakan adalah Quasi Experimental Design dengan Nonequivalent Control Grup Design seperti pada Tabel 2.

Tabel 2. Nonequivalent Group Design

\begin{tabular}{cccc}
\hline Kelas & Pretest & Perlakuan & Posttest \\
\hline JUCAMA & $\mathrm{O}$ & $\mathrm{X}$ & $\mathrm{O}$ \\
$\begin{array}{c}\text { Konvensio } \\
\text { nal }\end{array}$ & $\mathrm{O}$ & & $\mathrm{O}$ \\
\hline
\end{tabular}

Keterangan:

X: Pembelajaran JUCAMA (Pengajuan dan Pemecahan Masalah)

O: Pretest/posttest kemampuan berpikir kreatif matematis siswa pada kelas JUCAMA dan kelas konvensional.

\section{HASIL DAN PEMBAHASAN}

Data yang diperoleh dalam penelitian ini adalah data nilai tes kemampuan berpikir kreatif matematis siswa berdasarkan hasil pretest dan postest pada kelas JUCAMA dan kelas konvensional. Skor Pretest kelas JUCAMA dapat dilihat pada Gambar 1. Skor Pretest kelas kontrol dapat dilihat pada Gambar 2. Skor Posttest kelas JUCAMA dapat dilihat pada Gambar 3. Skor Posttest kelas kontrol dapat dilihat pada Gambar 4.

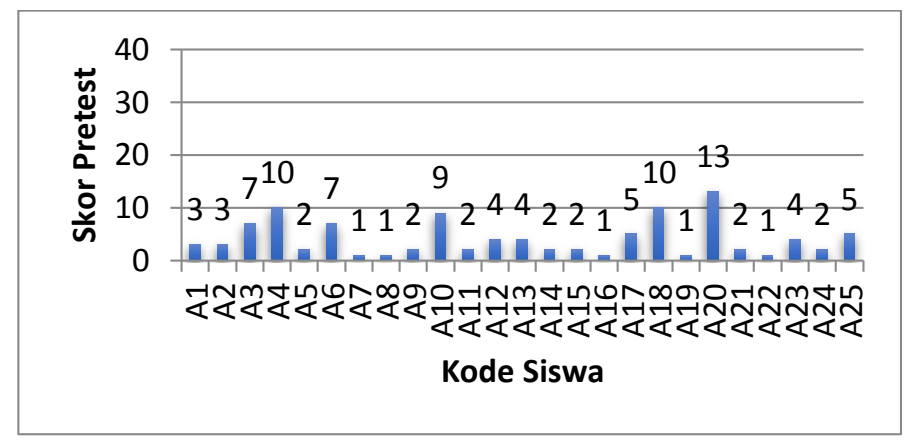

Gambar 1. Grafik Perolehan Skor Pretest Kelas JUCAMA.

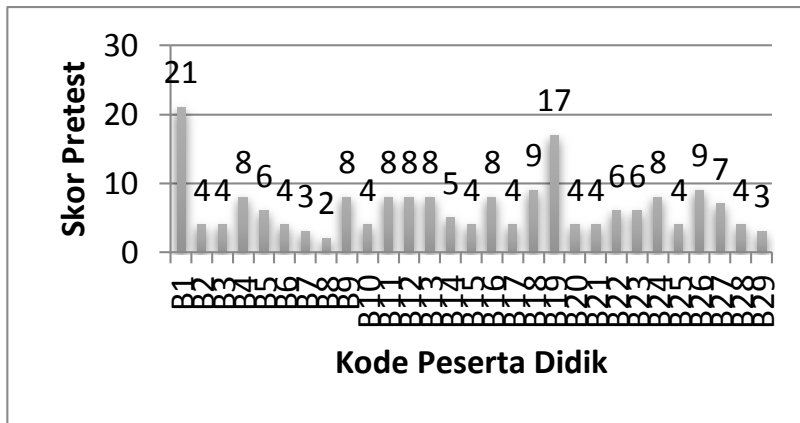

Gambar 2. Grafik Perolehan Skor Pretest Kelas Kontrol 

melalui penerapan model pembelajaran JUCAMA

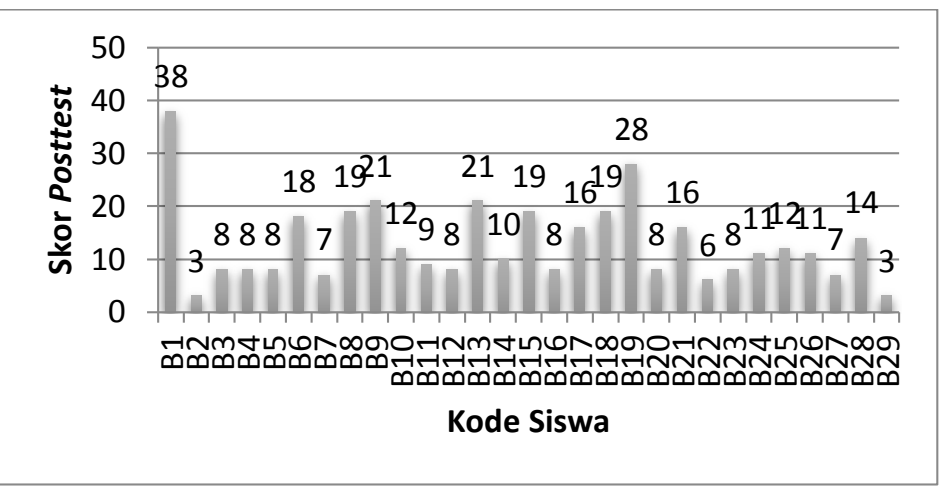

Gambar 3. Grafik Perolehan Skor Posttest Kelas JUCAMA

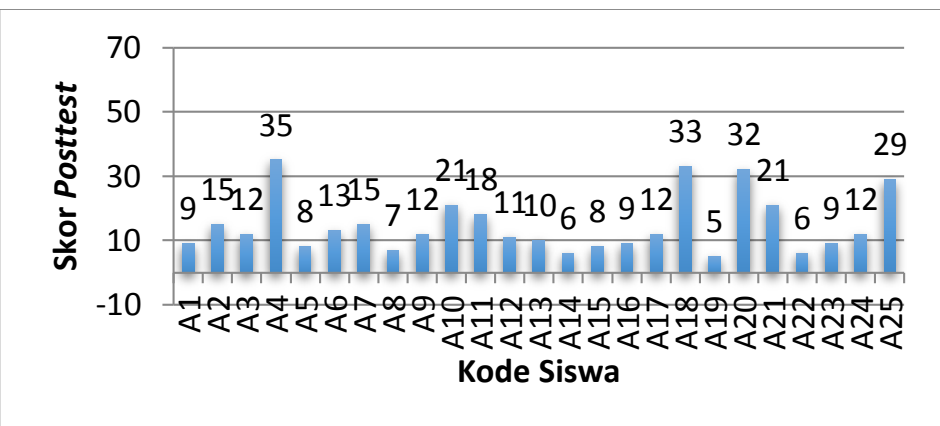

Gambar 4. Grafik Perolehan Skor Posttest Kelas Kontrol

Deskripsi data pretest kemampuan berpikir kreatif matematis siswa dapat dilihat hasilnya yaitu pada Tabel 3 menunjukkan bahwa ratarata skor siswa pada kelas JUCAMA adalah 4,12 dan skor pada kelas konvensional adalah 6,5 sehingga skor rata-rata yang diperoleh kedua kelas masih jauh dari skor ideal yaitu 70.

Tabel 3. Statistik Deskriptif Analisis Data Hasil Pretest

\begin{tabular}{ccccc}
\hline Kelas & n & $\begin{array}{c}\text { Nilai } \\
\text { Maks }\end{array}$ & $\begin{array}{c}\text { Nilai } \\
\text { Min }\end{array}$ & Mean \\
\hline JUCAMA & 25 & 13 & 1 & 4,12 \\
Konvensional & 29 & 21 & 2 & 6,5 \\
\hline
\end{tabular}

Tabel 4. Statistik Deskriptif Analisis Data Hasil Posttest

\begin{tabular}{ccccc}
\hline Kelas & n & $\begin{array}{c}\text { Nilai } \\
\text { Maks }\end{array}$ & $\begin{array}{c}\text { Nilai } \\
\text { Min }\end{array}$ & Mean \\
\hline JUCAMA & 25 & 35 & 5 & 14,7 \\
Konvensional & 29 & 38 & 3 & 12,9 \\
\hline
\end{tabular}

Dari data hasil pengujian posttest rata-rata skor siswa pada kelas JUCAMA dan kelas konvensional adalah 14,7 dan 12,9 jauh dari skor idealnya 70. Interpretasi lainnya bahwa rata-rata skor posttest kelas dengan pembelajaran JUCAMA lebih tinggi dari kelas konvensioanl dengan pembelajaran konvensional. Langkah selanjutnya yang dilakukan yaitu mencari skor peningkatan (NGain) yang diambil dari data hasil pretestposttest siswa kelas JUCAMA dan kelas konvensional. Lalu skor peningkatan tersebut dihitung dengan rumus sebagai berikut.

$$
\mathrm{N}-\text { Gain }=\frac{\text { skor }{ }_{\text {posttest }}-\text { skor }_{\text {pretest }}}{\text { skor }}
$$

Data N-Gain berdasarkan hasil pretest dan posttest kemampuan berpikir kreatif matematis pada kelas JUCAMA termuat dalam Gambar 5 .

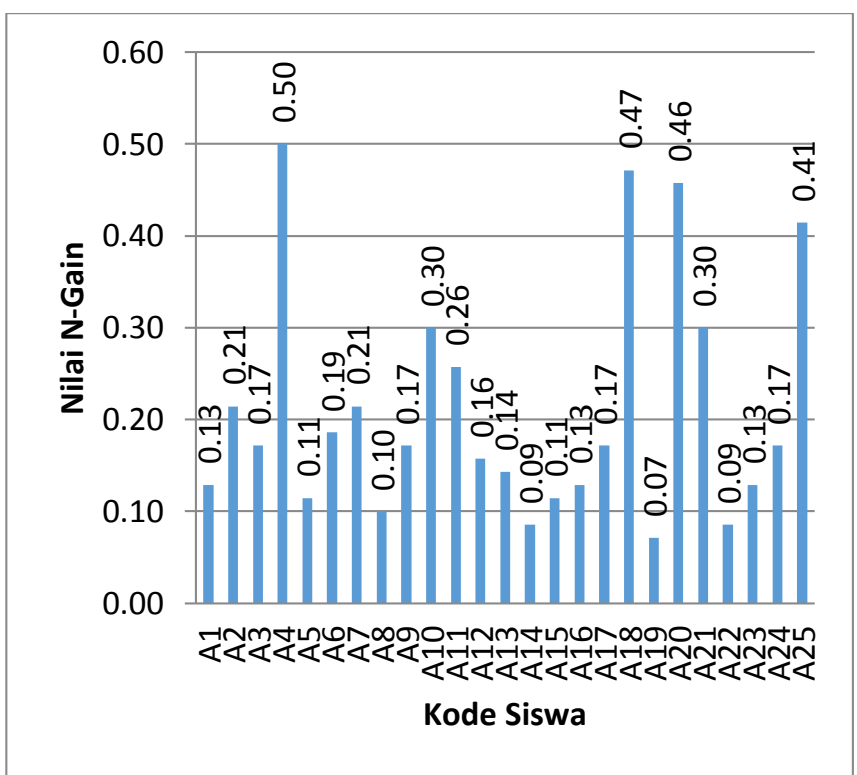

Gambar 5. Hasil N-Gain Kelas Eksperimen

Berdasarkan Gambar 1 nilai N-Gain terendah pada kelas JUCAMA adalah 0,07 dan skor tertinggi adalah 0,50 . Artinya, peningkatan kemampuan berpikir kreatif matematis di kelas JUCAMA masih belum maksimal. Adapun NGain kelas konvensional termuat dalam Gambar 6. Berdasarkan Gambar 6 interpretasinya 
adalah pada kelas konvensional nilai N-Gain terendah adalah 0,04 dan tertinggi adalah 0,54 . Artinya, peningkatan kemampuan berpikir kreatif matematis di kelas konvensional masih belum maksimal.

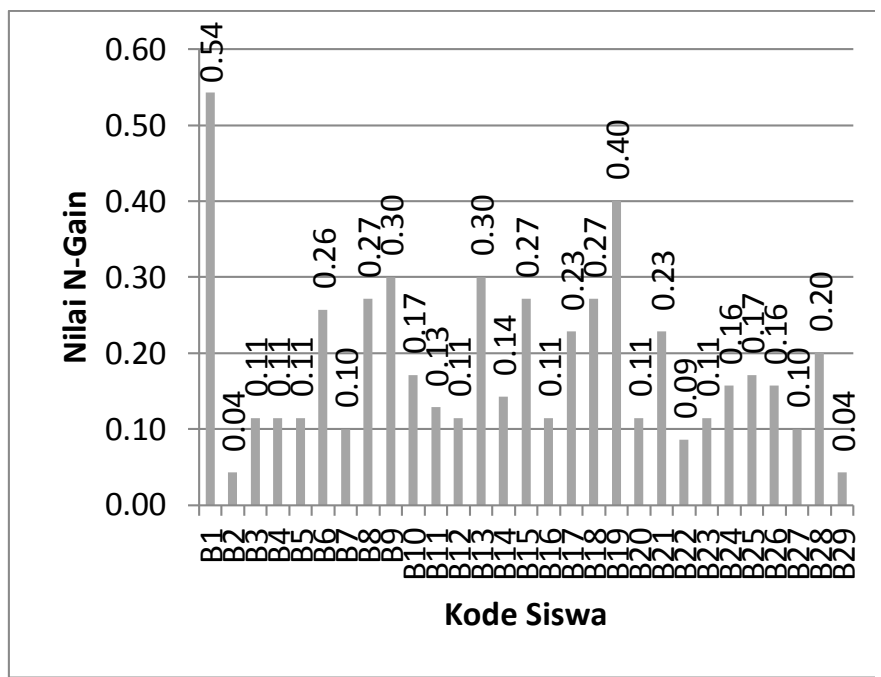

Gambar 6. Hasil N-Gain Kelas Konvensional

Analisis data N-Gain dapat dilihat pada Tabel 5.Hasinya mean atau rata-rata $\mathrm{N}$-Gain siswa pada kelas JUCAMA adalah 0,16 lebih tinggi dari kelas konvensional yaitu 0,10.

Tabel 5. Statistik Deskriptif Analisis Data Hasil NGain

\begin{tabular}{ccccc}
\hline Kelas & n & $\begin{array}{c}\text { Nilai } \\
\text { Maks }\end{array}$ & $\begin{array}{c}\text { Nilai } \\
\text { Min }\end{array}$ & Mean \\
\hline JUCAMA & 25 & 0,50 & 0,07 & 0,16 \\
$\begin{array}{c}\text { Konvensio } \\
\text { nal }\end{array}$ & 29 & 0,54 & 0,04 & 0,10 \\
\hline
\end{tabular}

Sebelum Uji T-Bebas / Uji T-Independent, data $\mathrm{N}-$ Gain perlu diuji kenormalitasan menggunakan Kolmogorof Smirnov dan diuji homogenitasnya dengan Uji Levene menggunakan SPSS 20.

Tabel 6. Hasil Uji Normalitas Data N-Gain dengan SPSS 20

\begin{tabular}{lrr}
\hline & JUCAMA & Konvensional \\
\hline N & 25 & 29 \\
Sig. & .173 & .275 \\
\hline
\end{tabular}

Meningkatkan kemampuan berpikir kreatif melalui penerapan model pembelajaran JUCAMA
Analisis SPSS 2omenunjukkan bahwa nilai Sig. pada kelas yang menggunakan JUCAMA sebesar $(0,173)>(0,05)$ maka data dianggap berdistribusi normal dan kelas konvensionaladalah $(0,275)>(0,05)$ maka data dianggap berdistribusi normal.

Selanjutkan akan dianalisis homogenitas varins dengan SPSS 20 sepertihasil pada Tabel 7.Analisis SPSS 20 ini menggunakan menu test of Homogeneity of variances, dari output yang tertera dapat disimpulkan sebagai bahwa Nilai Sig. $(0,841)>$ nilai signifikansi $(0,05)$ maka data dianggap memiliki varians yang homogen.

Tabel 7. Hasil Uji Homogenitas Varians Data NGain dengan SPSS 20

\begin{tabular}{rrrrr}
\hline $\begin{array}{c}\text { Levene } \\
\text { Statistic }\end{array}$ & df1 & \multicolumn{1}{c}{ df2 } & \multicolumn{1}{c}{ Sig. } \\
\hline .041 & & 1 & 52 & .841 \\
\hline
\end{tabular}

Data berdistribusi normal dan varians data homogen maka pengujian dilanjutkan dengan menggunakan uji T-Bebas untuk mengetahui perbedaanpencapaian kemampuan berpikir kreatif dari dua kelas yang diuji. Analisis SPSS $2 O$ uji T-Bebas menggunakan menu Independent-Sampet T Test, dari output yang tertera dapat dilihat dari nilai Sig.yaitu(0,031) < nilai signifikansi $(0,05)$ maka terdapat perbedaan signifikansi antara kedua sampel yang tertera pada Tabel 8.

Tabel 8. Hasil Uji T-Bebas Data N-Gain dengan SPSS 20

\begin{tabular}{clrr}
\hline F & t & df & Sig. \\
\hline .041 & 2.216 & 52 & 0.31 \\
\hline
\end{tabular}

Dalam penelitian ini juga dianalisis perbedaan pencapaian kemampuan berpikir kreatif berdasarkan kategori Pengetahuan Awal Matematika (PAM) baik tinggi, sedang, rendah. Hasilnya, tidak terdapat tidak terdapat perbedaan pencapaian kemampuan berpikir kreatif matematis yang signifikan antara siswa yang menggunakan model model Pembelajaran JUCAMA (Pengajuan dan Pemecahan Masalah) dengan siswa yang menggunakan pembelajaran konvensional pada faktor pembelajaran. Penggunaan model pembelajaran ini tidak 
Meningkatkan kemampuan berpikir kreatif melalui penerapan model pembelajaran JUCAMA

bergitu berpengaruh pada peningkatan kemampuan berpikir kreatif. Analisis yang dilakukan untuk melihat perbedaan pencapaian kemampuan berpikir kreatif matematis berdasarkan tingkat Pengetahuan Awal Matematika (PAM) tinggi, sedang, dan rendah secara statistik dapat dilakukan dengan uji ANOVA dua jalur. Adapun asumsi yang harus yaitu data harus berdistribusi normal dan memiliki varians yang homogen. Data diperoleh dari data posttest siswa berdasarkan kategori PAM.

Analisis kenormalan distribusi data dilakukan dengan menggunakan aplikasi SPSS 20 yang tertera pada Tabel 9.

Tabel 9. Hasil Uji Normalitas Data Skor Posttest dengan SPSS 20

\begin{tabular}{lrr}
\hline & N & Sig. \\
\hline EKS_T & 6 & .793 \\
EKS_S & 13 & .303 \\
EKS_R & 6 & .518 \\
KNT_T & 8 & .725 \\
KNT_S & 14 & .640 \\
KNT_R & 7 & .785 \\
\hline
\end{tabular}

Analisis SPSS 20 ini menggunakan menu One Sample $K-S$, dari output yang tertera dapat disimpulkan bahwa semua nilai Sig. untuk kolom semua kelompok lebih dari taraf signifikansi 0,05 maka semua kelompok memiliki data yang berdistribusi normal. Sedangkan analisis homogenitas varians yang dilakukan dengan menggunakan aplikasi SPSS 2O, menampilkan hasil perhitungan seperti pada Tabel 10. Analisis SPSS $2 O$ ini menggunakan menu test of Homogeneity of variances, dari output yang tertera dapat disimpulkan sebagai bahwa Nilai Sig. (o,058) $>\alpha \quad(0,05)$ maka data dianggap memiliki variansyang homogen.

Tabel 10. Hasil Uji Homogenitas Varians Data Posttest dengan SPSS $2 O$

\begin{tabular}{rrrr}
$\begin{array}{c}\text { Levene } \\
\text { Statistic }\end{array}$ & df1 & \multicolumn{1}{c}{ df2 } & Sig. \\
\hline 2.313 & 5 & 48 & .058 \\
\hline
\end{tabular}

Analisis SPSS 20 ini menggunakan menu test of Homogeneity of variances, dari output yang tertera dapat disimpulkan sebagai bahwa Nilai Sig. $(0,058)>\boldsymbol{\alpha}(0,05)$ maka data dianggap memiliki varians yang homogen.

Analisis dilanjutkan dengan menggunakan Uji Anova Dua Jalur karena semua kelompok kelompok data memenuhi asumsi normalitas data dan homogenitas varians dengan menggunakan aplikasi SPSS 20 diperoleh data seperti Tabel 11.

Tabel 11. Hasil Uji ANOVA Dua Jalur dengan SPSS $2 O$

\begin{tabular}{lrrc}
\hline & df & \multicolumn{1}{c}{ F } & Sig. \\
\hline Corrected Model & 5 & 8.825 & .000 \\
Intecept & 1 & 252.93 & .000 \\
Model_PAM & 1 & 1.320 & .256 \\
PAM & 2 & 21.445 & .000 \\
Model_Pemb*PAM & 2 & .446 & .643 \\
\hline
\end{tabular}

Dari hasil perhitungan pada Tabel 11 dapat disimpulkan sebagai berikut.

- Pada faktor Pembelajaran (Model_Pem) menunjukan bahwa Sig. (o,oo) < taraf signifikansi (0,05), maka adalah tidak terdapat perbedaan pencapaian kemampuan berpikir kreatif matematis yang signifikan antara siswa yang menggunakan model model Pembelajaran JUCAMA (Pengajuan dan Pemecahan Masalah) dengan siswa yang menggunakan pembelajaran konvensional.

- Pada faktor PAM menunjukan bahwa nilai sig $(0,25)<$ taraf signifikansi $(0,05)$, maka terdapat perbedaan pencapaian kemampuan berpikir kreatif matematis siswa berdasarkan Pemahaman Awal Matematika (PAM) yaitu: tinggi, sedang dan rendah. Hal tersebut menunjukan bahwa terdapat perbedaan pencapaian pada tingkat PAM siswa minimalnya satu yang berbeda.

- Pada faktor interaksi (Pembelajaran*PAM) menunjukan bahwa Sig. (o.643) >taraf signifikansi $(0,05)$, maka tidak terdapat 
interaksi yang signifikan antara penggunaan pembelajaran dengan tingkat PAM siswa.

Analisis dilanjutkan karena pada faktor PAM yang terdapat perbedaan pencapaian yaitu untuk mengetahui perbedaan signifikan dengan uji Post Hoc Tukey untuk pada kelompok PAM tinggi, sedang dan rendah. Analisis uji Post Hoc Tukey tertera pada Tabel 12.

Tabel 12.Hasil Uji Post Hoc Tukey dengan SPSS 20

\begin{tabular}{cccc}
\hline (I) PAM & (J) PAM & $\begin{array}{c}\text { Mean } \\
\text { Difference } \\
(\text { I-J) }\end{array}$ & Sig. \\
\hline \multirow{2}{*}{ Tinggi } & Sedang & $10.8624^{*}$ & .000 \\
& Rendah & $14.5604^{*}$ & .000 \\
\multirow{2}{*}{ Sedang } & Tinggi & -10.8624 & .000 \\
& Rendah & 3.6980 & .197 \\
Rendah & Tinggi & $-14.5604^{*}$ & .000 \\
& Sedang & -3.6980 & .197 \\
\hline
\end{tabular}

Berdasarkan hasil SPSS pada Tabel 12 dapat diambil beberapa kesimpulan, sebagai berikut.

- Nilai Sig. untuk pasangan PAM siswa tinggi dan siswa sedang yaitu $0,00<0,05$ maka $H_{o}$ ditolak. Artinya terdapat perbedaan terdapat perbedaan pencapaian kemampuan berpikir kreatif matematis antara siswa dengan kategori PAM tinggi dan siswa dengan kategori PAM sedang. Didapatkan nilai Mean Difference antar sebesar 10,86 artinya pencapaian kemampuan berpikir kreatif matematis siswa kelompok PAM tinggi lebih tinggi dari pencapaian siswa kelompok PAM sedang.

- Nilai Sig. untuk pasangan PAM siswa tinggi dan siswa rendah yaitu $0,00<0,05$ maka $H_{0}$ ditolak. Artinya terdapat perbedaan terdapat perbedaan pencapaian kemampuan berpikir kreatif matematis antara siswa dengan kategori PAM tinggi dan siswa dengan kategori PAM rendah. PAM tinggi dan siswa dengan kategori PAM sedang. Didapatkan nilai Mean Difference antar sebesar 14,56 artinya pencapaian kemampuan berpikir kreatif matematis siswa kelompok PAM
Meningkatkan kemampuan berpikir kreatif melalui penerapan model pembelajaran JUCAMA tinggi lebih tinggi dari pencapaian siswa kelompok PAM rendah.

- Nilai Sig. untuk pasangan PAM siswa sedang dan siswa tinggi yaitu $0,00<0,05$ maka $H_{o}$ ditolak. Artinya terdapat perbedaan terdapat perbedaan pencapaian kemampuan berpikir kreatif matematis antara siswa dengan kategori PAM sedang dan siswa dengan kategori PAM tinggi.

- Nilai Sig. untuk pasangan PAM siswa sedang dan siswa rendah yaitu 0,197 < 0,050 maka $H_{o}$ diterima. Artinya tidak terdapat perbedaan terdapat perbedaan pencapaian kemampuan berpikir kreatif matematis antara siswa dengan kategori PAM sedang dan siswa dengan kategori PAM rendah. PAM tinggi dan siswa dengan kategori PAM sedang. Didapatkan nilai Mean Difference antar sebesar 3,69 artinya pencapaian kemampuan berpikir kreatif matematis siswa kelompok PAM tinggi lebih tinggi dari pencapaian siswa kelompok PAM sedang namun pada kelompok ini tidak ada perbedaan yang signifikan.

- Nilai Sig. untuk pasangan PAM siswa rendah dan siswa tinggi yaitu $0,00<0,05$ maka $H_{o}$ ditolak. Artinya terdapat perbedaan terdapat perbedaan pencapaian kemampuan berpikir kreatif matematis antara siswa dengan kategori PAM rendah dan siswa dengan kategori PAM tinggi.

- Nilai Sig. untuk pasangan PAM siswa rendah dan siswa sedang yaitu $0,00<0,05$ maka $H_{o}$ diterima. Artinya tidak terdapat perbedaan terdapat perbedaan pencapaian kemampuan berpikir kreatif matematis antara siswa dengan kategori PAM rendah dan siswa dengan kategori PAM sedang.

Selanjutnya, dapat dilihat interaksi antara PAM siswa dengan pembelajaran dalam perbedaan kemampuan berpikir kreatif matematis tertera pada Gambar 7. 


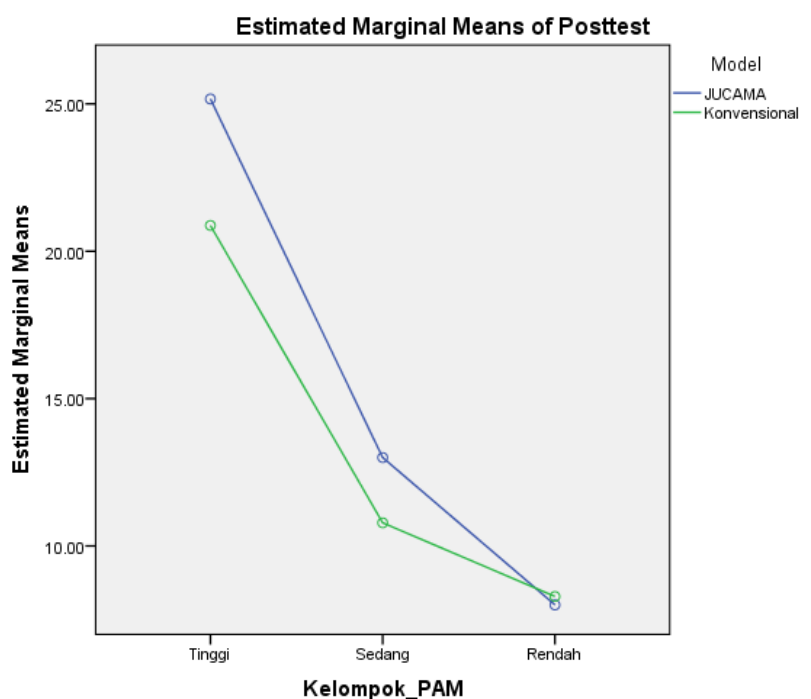

Gambar 7. Interaksi antara PAM dengan Model Pembelajaran dalam Perbedaan Kemampuan Bepikir Kreatif Matematis Siswa.

Berdasarkan Gambar 7 didapatkan bahwa:

- Kelas yang menggunakan model pembelajaran JUCAMA (Pengajuan dan Pemecahan Masalah) dengan kategori PAM tinggi lebih baik dari kategori sedang dan rendah serta lebih baik dari yang menggunakan model konvensional kategori PAM tinggi, sedang dan rendah.

- Kelas yang menggunakan model pembelajaran JUCAMA (Pengajuan dan Pemecahan Masalah) dengan kategori PAM sedang lebih baik dari kategori rendah serta lebih baik dari yang menggunakan model konvensional kategori PAM sedang dan rendah.

- Kelas yang menggunakan model pembelajaran JUCAMA (Pengajuan dan Pemecahan Masalah) dengan kategori PAM rendah tidak lebih baik dari yang menggunakan model konvensional kategori PAM rendah.

Untuk melihat perbedaan kemampuan berpikir keatif siswa yang mendapat model pembelajaran JUCAMA (Pengajuan dan
Meningkatkan kemampuan berpikir kreatif melalui penerapan model pembelajaran JUCAMA

Pemecahan Masalah) dengan siswa yang mendapat model pembelajaran konvensional dapat dilihat dalam Tabel 13.

Tabel 13. Analisis Perbandingan PAM dengan Software SPSS 20

\begin{tabular}{lll}
$\begin{array}{c}\text { (I) } \\
\text { Kelompok_ } \\
\text { PAM }\end{array}$ & $\begin{array}{c}\text { (J) } \\
\text { Kelompok_PaM } \\
\text { PAM }\end{array}$ & $\begin{array}{c}\text { Mean } \\
\text { Difference } \\
\text { (I-J) }\end{array}$ \\
\hline EKS_T & KNT_T & 4.2917 \\
\hline EKS_S & KNT_S & 2.2143 \\
\hline EKS_R & KNT_R & -.2857 \\
\hline
\end{tabular}

Berdasarkan Tabel 13 didapatkan bahwa:

- $\quad$ Tidak terdapat perbedaan signifikan antara siswa dengan PAM tinggi model pembelajaran JUCAMA (Pengajuan dan Pemecahan Masalah) dengan model pembelajaran konvensional. Namun, kelas dengan pembelajaran JUCAMA (Pengajuan dan Pemecahan Masalah) PAM tinggi dengan perbedaan rata-rata 4,29 lebih tinggi dari kelas konvensional PAM tinggi.

- $\quad$ Tidak terdapat perbedaan signifikan antara siswa dengan PAM sedang model pembelajaran JUCAMA (Pengajuan dan Pemecahan Masalah) dengan model pembelajarn konvensional. Namun, kelas dengan pembelajaran JUCAMA (Pengajuan dan Pemecahan Masalah) PAM sedang dengan perbedaan rata-rata 2,21 lebih tinggi dari kelas konvensional PAM tinggi.

- $\quad$ Tidak terdapat perbedaan antara siswa dengan PAM rendah model pembelajaran JUCAMA (Pengajuan dan Pemecahan Masalah) dengan model pembelajaran konvensional. Namun, kelas dengan pembelajaran JUCAMA (Pengajuan dan Pemecahan Masalah) PAM rendah dengan perbedaan rata-rata -0,29 lebih rendah dari kelas konvensional PAM rendah.

Dengan adanya perbedaan peningkatan kemampuan berpikir kreatif ini maka terlihat sistem pendidikan berbasasis masalah ini menjadi lebih baik. Hal ini Sejalan dengan Vegas yang enyatakan bahwa sistem pendidikan 
Meningkatkan kemampuan berpikir kreatif melalui penerapan model pembelajaran JUCAMA

yang berhasil di sekolah adalah sistem yang melekat pada pemecahan masalah dan menggabungkan konteks masalah dengan informasi, misalnya penggunaan matematika dan sains untuk memecahkan masalah praktis (Wrahatnolo and Munoto, 2018).

Dalam perubahan dunia di abad ke-21 ini, pentingnya kreativitas sulit untuk dilebihlebihkan. Amando dkk dalam Elgrably dan Leikin (2021) menyebutkan bahwa pengembangan kreativitas secara umum dan khususnya kreativitas matematika sangat Selanjutnya Torrance menganggap kreativitas sebagai kombinasi yang efektif dari pemikiran divergen dan konvergen. Kreativitas matematika dalam matematika di sekolah biasanya dikaitkan dengan pemecahan masalah atau problem posing. Pengajuan masalah dan pemecahan masalah dapat digunakan untuk pengembangan kreativitas matematika (Elgraby dan Leikin, 2021)

\section{KESIMPULAN}

Berdasarkan penelitian yang telah dilakukan, terdapat beberapa temuan yang akan disampaikan oleh peneliti tentang model pembelajaran JUCAMA (Pegajuan dan Pemecahan Masalah). Pertama mengenai perbedaan peningkatan Kemampuan berpikir kreatif matematis, kedua tentang perbedaan pencapaian kemampuan berpikir kreatif matematis berdasarkan tingkat Pengetahuan Awal Matematis (PAM) yang diketegorikan Tinggi, Sedang, dan Rendah.

Berdasarkan nilai gain ternormalisasi dari kedua kelas sampel ditemukan perbedaan ratarata hasil peningkatan sebesar 0,06 yang mana peningkatan lebih baik untuk siswa yang menggunakan model pembelajaran JUCAMA (Pengajuan dan Pemecahan Masalah) dengan rata-rata 0,16 juga lebih tinggi dari siswa yang menggunakan pembelajaran konvensional sebesar 0,10. Untuk melihat apakah terdapat perbedaaan signifikan mengenai peningkatan tersebut dilakukan analisis perbedaan rata-rata dengan Uji t-bebas yang hasilnya adalah terdapat perbedaan peningkatan kemampuan berpikir kreatif siswa yang menggunakan model pembelajaran JUCAMA (Pengajuan dan Pemecahan Masalah) dengan siswa yang menggunakan pembelajaran konvensional.

Dengan analisis statistik ditemukan tentang pencapaian kemampuan berpikir kreatif matematis antara siswa yang mendapatkan model pembelajaran JUCAMA (Pengajuan dan Pemecahan Masalah) dengan yang mendapatkan pembelajaran konvensional (Pembelajaran Langsung) dimana hanya diperoleh perbedaan pencapaian kemampuan berpikir kreatif matematis siswa berdasarkan Pengetahuan Awal Matematika (PAM) yaitu: tinggi, sedang dan rendah. Hal tersebut menunjukan bahwa terdapat perbedaan pencapaian pada siswa PAM rendah dengan siswa PAM Tinggi.

\section{REFERENSI}

Agustina, W., \& Noor, F. (2016). Hubungan hasil belajar dan tingkat berpikir kreatif siswa dalam pembelajaran matematika. Math Didactic: Jurnal Pendidikan Matematika, 2(3), 191-200.

Bona, M. F. (2019). Guru Sulit Ajarkan Siswa untuk Berpikir Kreatif. (https://www.google.com/amp/s/amp.be ritsatu.com/nasional/550513/guru-sulitajarkan-siswa-untuk-berpikir-kreatif/) diakses 8 Januari 2020

Elgrably, H., \& Leikin, R. (2021). Creativity as a function of problem-solving expertise: posing new problems through investigations. ZDM-Mathematics Education, 1-14

Fox, S., \& Surtees, L. (2010). Mathematics across the curriculum: Problem-solving, reasoning and numeracy in primary schools. A\&C Black.

Hendriana, H., \& Soemarmo, U. (2017). Penilaian Pembelajaran Matematika. (N. F. Latif, Ed.). Bandung: PT Refika Aditama. 
Mulyaningsih, T., \& Ratu, N. (2017). Analisis Kemampuan Berpikir Kreatif Siswa SMP dalam Memecahkan Masalah Matematika Pada Materi Pola Barisan Bilangan. Jurnal Ilmiah Pendidikan Matematika, 3(1), 65-

74 .

Pehkonen, E. (1997). The State-of-Art in Mathematical Creativity. International Reviews on Mathematical Education, 29(3), 63-67. (https://www.emis.de/journals/ZDM/zd m973i.html) diakses pada tanggal 2 Januari 2020

Shalahuddin, H., Susanto, H., \& Parta, I. N. (2019). Identifikasi Level Berpikir Kreatif Siswa dalam Menyelesaikan Soal Cerita Open Ended pada Materi SPLTV.Jurnal Pendidikan : Teori, Penelitian \& Pengambangan, 4(2), 188-195.

Siagan, M. V., Saragih, S., \& Sinaga, B. (2019). Development of Learning Materials Oriented on Problem-Based Learning Model to Improve Students' Mathematical Problem Solving Ability and Metacognition Ability. International electronic journal of mathematics education, 14(2), 331-340.

Silver, E. A. (1997). Fostering Creativity through Instruction Rich in Mathematical Problem Solving and Problem Posing. International Reviews on Mathematical Education, 29(3), 75-80.

Siswono, T. Y. E. (2018). Pembelajaran Matematika Berbasis Pengajuan dan Pemecahan Masalah Fokus Pada Berpikir Kritis dan Berpikir Kreatif. Bandung: PT Remaja Rosda Karya.

Wrahatnolo, T. (2018). 21st centuries skill implication on educational system. In IOP Conference Series: Materials Science and Engineering (Vol. 296, No. 1, p. 012036). IOP Publishing.

Xie, J., \& Masingila, J. O. (2017). Examining interactions between problem posing and problem solving with prospective primary teachers: A case of using fractions. Educational Studies in
Mathematics, 96(1), 101-118. 